\title{
Private Credit under Political Influence: Evidence from France ${ }^{\star}$
}

Anne-Laure Delatte ${ }^{\dagger}$, Adrien Matray ${ }^{\dagger \dagger}$ \& Noémie Pinardon-Touati ${ }^{\ddagger}$

\section{Highlights}

- We examine French credit registry data for 2007-2017.

- We find that credit granted to the private sector increases by $9 \%-14 \%$ in the year during which a powerful incumbent faces a contested election.

- Banks that grant more credit to private firms in election years gain market share in the local public entity debt market after the election is held.

* For helpful suggestions and feedback, we would like to thank Denis Gromb, Johan Hombert, Jean Imbs, Janis Skratnis and Vikrant Vig as well as various seminar and conference participants at ACPR, CEPII, HEC Paris, Lille University, Sciences Po Paris, PSE, Universitat de Barcelona, EFA.

† CNRS (Dauphine-Leda), CEPII, CEPR.

†† Princeton University.

$\ddagger$ HEC Paris. 


\section{Abstract}

Formally independent private banks change their supply of credit to the corporate sector for the constituencies of contested political incumbents in order to improve their reelection prospects. In return, politicians grant such banks access to the profitable market for loans to local public entities among their constituencies. We examine French credit registry data for 2007-2017 and find that credit granted to the private sector increases by $9 \%-14 \%$ in the year during which a powerful incumbent faces a contested election. In line with politicians returning the favor, banks that grant more credit to private firms in election years gain market share in the local public entity debt market after the election is held. Thus we establish that, if politicians can control the allocation of rents, then formal independence does not ensure the private sector's effective independence from politically motivated distortions.

\section{Keywords}

Politics and Banking, Moral Suasion, Local Government Financing.

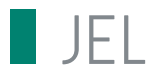

G21, G30, H74, H81.

\section{Working Paper}

\section{CEPI}

CEPII (Centre d'Etudes Prospectives et d'Informations Internationales) is a French institute dedicated to producing independent, policyoriented economic research helpful to understand the international economic environment and challenges in the areas of trade policy, competitiveness, macroeconomics, international finance and growth.

CEPII Working Paper
Contributing to research in international
economics
@ CEPII, PARIS, 2020
All rights reserved. Opinions expressed
in this publication are those of the
author(s) alone.

Editorial Director: Sébastien Jean

Production: Laure Boivin

Published on 06.05.20

No ISSN: $1293-2574$
CEPII

20, avenue de Ségur TSA 10726 75334 Paris Cedex 07 +33153685500 www.cepii.fr Press contact: presse@cepii.fr 


\section{Introduction}

The capacity of politicians to allocate large rents can distort the behavior of firms, which have incentives to accommodate politicians' needs in order to gain access to those rents. There are many ways firms can help politicians, ranging from small (legal) political contributions to outright corruption, in addition to boosting short-term economic activity before elections. A politician can reciprocate by granting those firms access to the rents under her control. One well-known example is local public markets and government contracts - which is precisely why, in developed economies, such markets have become heavily regulated by public procurement codes that promote competition.

One chief contribution of this paper is to uncover a large and profitable market-controlled entirely by politicians - that regulators have overlooked: the market for loans to local public entities (e.g., local governments, public hospitals, schools). In most OECD countries, this multi-billion-dollar market is highly profitable because loans are as safe as government bonds yet offer higher interest rate.1 However, this market is excluded from public procurement codes and its access is controlled by local politicians.

These three characteristics (size, profitability, and discretionary allocation) are important because they highlight the need to rethink the possibility of distortions due to influence-seeking behaviors and outdated banking regulations. The focus of regulation has traditionally been on enforcing the formal independence of banks from politicians. Indeed, if a politician directly controls the allocation of credit-because banks are government owned or because she can influence that allocation from his position on the bank's credit committee-then she will naturally be tempted to distort the credit allocation for political gain (e.g., to improve his reelection

\footnotetext{
${ }^{1}$ In many countries, public entities enjoy an explicit guarantee by the central government. In this respect, the United States-where, for instance, municipalities can default and go bankrupt-is more of an exception. In most developed countries, those outcomes are not possible. For example, local governments in France cannot go bankrupt; in the event of an unsustainable deficit, they are placed under the supervision of a representative of the central government (the "préfet") who cuts local spending and increases local taxes until creditors are repaid. This procedure is extremely rare, however: it was applied to fewer than 15 of 36,000 municipalities in 2016.
} 
prospects) ${ }^{2}$ This is the rationale behind regulatory efforts to ensure that banks are strictly independent from politicians.

Yet the absence of adequate public procurement regulation has enabled politicians to control access to a valuable market, and even a bank that is formally independent might have incentives to cater to their needs. As profit-maximizing private banks may be willing to help a political incumbent remain in office if they can gain favors in return, what our study confirms.

In this paper, we provide evidence (a) that formally independent banks alter their lending decisions to bestow favors on politicians and (b) that they do so in order to gain preferential access to the local public entity debt market. We exploit data from the French credit registry for the period 2007-2017 in combination with newly hand-collected data on French local elections and politicians. These data allow us to classify political incumbents along two dimensions: their political influence and the competitiveness of their elections. The French credit registry also tracks loans granted by banks to local public entities.

Our study yields three main findings. First, banks increase their lending to firms within a constituency before an election-and especially when the political incumbent is influential, the election is contested, and/or the bank has previously participated in the local public entity debt market. Second, we find this additional credit to be systematically targeted at companies in declining industries. Third, banks that lend more prior to an election see their market share of the local public entity debt market increase if the incumbent is reelected.

To inform the identification strategy, we first present a framework based on a "quid pro quo" political model of the interplay between private banks and politicians (Grossman and Helpman (2001)) in which politicians help firms in return for personal benefits such as votes. In this setting, the expectations are that banks will distort their credit policy when: (i) the political

\footnotetext{
${ }^{2}$ For the role of government-owned banks in developing countries, see Dinç (2005); Khwaja and Mian (2005); Claessens, Feijen, and Laeven (2008); Cole (2009); Carvalho (2014). For developed countries, see Sapienza (2004). For the role of politicians chairing a supervisory board, see Bian, Haselmann, and Vig (2017); Haselmann, Schoenherr, and Vig (2018).
} 
incumbent faces a close election; (ii) she has a high level of influence over the allocation of public entity debt; and (iii) banks are both willing and able to participate in the market for loans to local public entities.

Therefore, our identification strategy relies on three sources of variation. The first is variation in politicians' incentives to gain a favor, which is linked in turn with variation in time due to the electoral cycle and with variation across constituencies in the intensity of political competition. The second source of variation is across constituencies in politicians' influence over the local public entity debt market, and the third — within time and constituencies - is variation across banks in their incentives to participate in the public entity debt market.

We assess political competition by identifying as "contested" those constituencies for which the political incumbent is of a different party than her predecessor or for which the upcoming election result is close. What is relevant for banks in the return of favors is the politician's influence over the allocation of public entity loans; we therefore focus on "powerful" politicians, defined as those who have been in office for at least three terms and who belong to the same party as other local politicians heading the main debt-taking local government entities. To obtain variation across banks for a given constituency and time, we identify a bank's greater likelihood to participate in the market for public entity debt based on the presence of public entity loans in its portfolio

We start by showing that, in an election year, private banks' credit to the private sector in constituencies where the election is contested is $9 \%$ higher if the political incumbent is powerful. When we focus on non-powerful politicians and compare contested and non-contested constituencies in election years, we find that banks do not alter their supply of credit-an outcome that rules out our results being driven by different credit growth trends for constituencies that do versus do not experience contested elections.

Results at the constituency-year level do not distinguish between changes in credit supply and in credit demand. The latter may reflect, for instance, implementation of demand-side poli- 
cies by powerful contested incumbents or the uncertainty created by an upcoming contested election 3 To confirm that our baseline effect is driven by a change in credit supply, we exploit an additional source of heterogeneity across banks - namely, within constituency-year. We can then estimate the distortion of credit to the private sector across banks in the same constituency and at the same time; this approach has the additional advantage of allowing us to include constituency-by-time fixed effects and thereby control for unobserved time-varying heterogeneity across constituencies (e.g., differences in local economic growth, local policies, and uncertainty). We find that the increase in credit to the private sector in constituencies with contested powerful politicians is driven exclusively by banks holding public entity debt on their balance sheets. These banks increase their supply of credit to the local economy by $14 \%$ relative to banks in the same constituency but with no government debt on their respective balance sheets.

Our next task is to identify which firms benefit more from such credit expansion. In accord with the notion that this credit is used to support firms in the short run, we find that it is targeted at firms operating in sectors that are more dependent on short-term financing (i.e., firms with more working capital and higher interest repayments relative to revenues) and in declining sectors (i.e., sectors characterized by a higher probability of bankruptcy and lower value-added per asset).

Finally, we examine whether politicians reward a bank that increased its credit supply during an election year by providing post-election access to the market for loans to local public entities. Toward that end we build, for each constituency and each election, a measure of a given bank's support to the incumbent's reelection effort: the additional supply of credit during the election year (after removing baseline heterogeneity across constituencies and banks). We then relate this measure to changes in the bank's amount of loans to local public entities in that constituency. Regression results indicate that more supportive banks see an increase in their share of the

\footnotetext{
${ }^{3}$ See Julio and Yook (2012); Gulen and Ion (2015); Baker, Bloom, and Davis (2016); Jens (2017). These two effects influence credit demand in opposite directions. Whereas demand-side policies should boost economic activity and hence lead to higher credit demand, heightened uncertainty leads to lower investment and thus to reduced credit demand. If the second effect dominates, then our baseline specification underestimates the effect of reciprocal favors on the credit supply.
} 
market for loans to local public entities in the constituency after an election in which the political incumbent is reelected. However, if the incumbent loses then the more supportive banks see their market shares decline. This result is consistent with banks that supported the incumbent being rewarded if she is re-elected and, otherwise, being punished by the newly elected politician. Although these effects hold when we consider all loans to local public entities, we demonstrate that they are solely driven by loans to the local public entities controlled by local political incumbents-and not by loans to entities located in the same constituencies but controlled by the central government.

Our findings have two broad implications. First, they underscore the need for regulators to go beyond easily observable measures of independence-that is, because neither privatizing government-owned banks nor banning politicians from banks' credit committees will guarantee true independence if politicians retain unchecked influence over the allocation of access to profitable markets. Discretionary access to rents will create distortions in the behavior of banks (and of private firms more generally) as they seek seek favors from politicians. It follows that we must adopt a broader perspective when designing regulations and, in particular, must control more strictly the mechanisms by which loans are allocated to local public entities.

Second, our results point to real consequences for the allocation of credit. If politicians systematically direct credit toward declining sectors, thus hampering both the reallocation of resources to more productive firms and the process of creative destruction, then we can expect economic growth to be affected in the long run.

Related literature. Our work is perhaps most directly related to the literature on political business cycles (Nordhaus (1975)), which emphasizes that political incumbents who directly control banks have incentives to manipulate credit for the purpose of affecting election outcomes-in both emerging and developed countries where banks are state owned (Sapienza (2004); Dinç (2005); Khwaja and Mian (2005); Claessens, Feijen, and Laeven (2008); Cole (2009); Carvalho (2014); Bircan and Saka (2019)) as well as in cases of bailed-out banks (e.g., Chavaz and Rose 
(2018)) or banks whose supervisory board chairman is a politician (Bian, Haselmann, and Vig (2017); Englmaier and Stowasser (2017); Haselmann, Schoenherr, and Vig (2018); Koetter and Popov (2019)). 4 Yet regardless of whether banks are fully state owned or directly supervised by a politician, the policy implication is the same: formal independence should be enough to prevent politically motivated credit cycles.

Our chief contribution here is to uncover a political credit cycle for formally independent banks when campaign contributions are not allowed, other forms of direct lobbying and spending are extremely restricted, and bailouts are not necessary. This finding is critical for two reasons. First, in most countries, private banks account for most of the credit extended to corporations. Second, the implication is that addressing only the formal mechanisms of governance will not be enough to ensure the needed separation between politicians and firms.

This paper contributes also to the literature on favors between politicians and business elites. The bulk of that literature focuses on corruption, which is illegal, or on campaign contributions and lobbying (e.g. Akey (2015)), which are heavily regulated (if not banned) in most developed countries outside the United States. $5^{5}$ Scholars have studied various forms of political connections, such as former employment in government (Faccio (2006)), geographical ties (Faccio and Parsley (2009)), party affiliation (Ferguson and Voth (2008)), and educational ties (Nguyen and Nielsen (2010); Cohen and Malloy (2014); Bertrand, Kramarz, Schoar, and Thesmar (2018)).

Several papers have identified specific channels through which politicians can extend favors to firms. Examples include: preferential government economic policy, such as government bailouts (Brown and Dinç (2005); Faccio, Masulis, and McConnell (2007)); stimulus funding (Duchin and Sosyura (2012); Adelino and Dinç 2014; Bian, Haselmann, Kick, and Vig (2018)); and,

\footnotetext{
${ }^{4}$ The German savings bank sector is a good example of this phenomenon, which is associated with political credit cycles or pure rent extraction that favors the local business elite connected to politicians-even if it seems the politicians themselves receive nothing in return.

${ }^{5}$ For earlier reviews of the literature on campaign contributions, see Grossman and Helpman (2001); Ansolabehere, de Figueiredo, and Snyder (2003). On lobbying, see Vidal, Draca, and Fons-Rosen (2012) and Bertrand, Bombardini, and Trebbi (2014) or, from a more structural perspective, Kang (2016). On corruption, see the survey by Olken and Pande (2012).
} 
more broadly, legislation on issues of concern to firms in the politicians' districts (Mian, Sufi, and Trebbi (2010); Cohen and Malloy (2014)). Politicians have also been found to reciprocate by enabling easier access to government contracts - in the United States (Goldman, Rocholl, and So (2013); Tahoun (2014); Faccio and Hsu (2017)), in Denmark (Amore and Bennedsen (2013)), and in South Korea (Schoenherr (2019)) — and by delaying legal enforcement as well as by less stringent regulatory enforcement in the banking industry (Akey, Dobridge, Heimer, and Lewellen (2018); Akey, Heimer, and Lewellen (2018)).

Our contribution to this field is twofold. First, we identify a large, unregulated, and profitable market over which politicians have full discretion, one that makes a large distortion possible: the market for bank loans to local public entities. This market is not specific to France; rather, it is frequently used in the financing of most local public entities across developed countries-where, as in France, it is not regulated. As a result, the generalizability of the distortion we reveal is potentially high.

The paper's second contribution here is in its clearly establishing the existence of each sequential element in the two-way return of favors at the center of quid pro quo models. In fact, we show that (a) a bank's favor prior to the election is paid back by the reelected politician in the form of increased access to the market of public entity loans and (b) this payback is a direct function of the favor granted by the bank before the election. These results justify our modeling the firm's favor as an "input" to a production function that produces an "output" whose size depends on the input's value. Modeling of this type has become a workhorse in quid pro quo theories. In this respect, our paper is neither about "political connections", whereby politicians help their CEO friends (and vice versa), nor about establishing the existence of a political cycle in different countries. Instead, we aim to show how the existence of rents whose allocation is discretionary can distort not only political but also economic behavior. As such, our paper differs fundamentally from Bertrand, Kramarz, Schoar, and Thesmar (2018), who document the existence of a political employment cycle around elections that is driven by chief executive officers connected to local politicians with whom they graduated from the same elite school. In 
this case, CEOs are willing to forgo profits and receive nothing in return for the sake of doing one-way favors for their university friends.

\section{Institutional background}

\subsection{The French political system}

This analysis focuses on a subset of politicians - members of parliament (MPs), or députéswho sit in the French National Assembly, the lower house of parliament. ${ }^{6}$ Each MP is elected by a specific constituency through a two-round voting system. There are 577 constituencies, but we restrict our attention to those located in mainland France (including Corsica); thus we study 555 constituencies before the 2010 redistricting and 539 afterwards. The term of the National Assembly is five years unless it is dissolved by the president's calling for new elections. Elections occur in all constituencies at the same time (except when there are special elections, as when when an MP has resigned or died). Because many MPs also hold positions as city mayors, our analysis accounts for that additional electoral cycle.

Given their role on the national stage, MPs are usually among the most prominent figures of their party. So despite the absence of any formal requirement, previous experience in the MP role typifies most ministers and key members of the government as well as all presidential candidates of both parties since the 1960s (with the notable exception of Emmanuel Macron).

Although MPs are elected within a specific geographical entity, they need not always hold executive positions at the local level; even so, they can affect the allocation of public entity debt through two distinct channels. First, because MPs are leading figures in their respective parties, they can influence other elected members of their party-mayors, presidents of regions, and so

\footnotetext{
${ }^{6}$ Senators who sit in the parliament's upper house are not directly elected by citizens. Our study is restricted to MPs, who are directly exposed to the popular vote.
} 
forth—who do make financial decisions. Indeed, their endorsement is necessary for these local politicians to run under the party name and hence to benefit from the party's logistical support.7 Second, it is common during our sample period for an MP to be elected also as mayor of the largest city in her constituency or as president of the region in which that constituency resides (for an economic analysis of this phenomenon, see e.g. Bach (2011)).

\subsection{The financing of local public entities}

Our analysis relies on the hypothesis that banks are willing to grant politicians election favors in order to access the market for loans to local public entities. The question is: Why would private profit-maximizing banks be willing to distort their credit allocation to the local economy, an a priori costly decision, to gain access to this market? A plausible explanation is that this segment of the debt market is large, allocated by local politicians, and highly profitable for banks.

The market for debt of local governments and public institutions (e.g., hospitals, public housing) is large and consists mostly of bank debt. Over our sample period (2007-2018), the total debt of local public entities amounted to $€ 212$ billion, of which $80 \%$ was in the form of bank debt. 8

Table 1 breaks down bank debt to local public entities by categoriesduring 2007-2017. The vast majority of bank debt is medium/long-term credit allocated to local governments to finance capital expenditures — for example, on roads and sidewalks, public transportation, tunnels, public housing, schools, forests, and libraries 9

It is crucial for our purposes that politicians have complete control over their debt-related deci-

\footnotetext{
${ }^{7}$ Endorsement is crucial in France for two reasons. First, barring the recent exception of presidential elections, France does not hold "primary" elections. Hence the party's leaders themselves decide which candidate to sponsor in a local election. Second, political contributions are heavily regulated and political parties are directly funded by the government. This setup makes it virtually impossible for an independent candidate to raise the necessary campaign funding.

${ }^{8}$ In 2016, bank debt accounted for $82 \%$ of the total debt of local governments (municipalities, departments, and regions) and for $88 \%$ of total hospital debt.

9 In France, four levels of local governments are allowed to sign loan contracts: communes, départements, régions, and $\mathrm{EPCl}$ (Etablissement public de coopération intercommunale).
} 
Table 1 - Bank Debt of Public Entities

\begin{tabular}{lccccc}
\hline & \multicolumn{2}{c}{ Short-term credit } & & \multicolumn{2}{c}{ Medium/long-term credit } \\
\cline { 2 - 3 } \cline { 5 - 6 } Type & Vol. $(€ \mathrm{mn})$ & Share & & Vol. $(€ \mathrm{mn})$ & Share \\
\hline Central government & 187 & $2.7 \%$ & & 1,794 & $1.1 \%$ \\
Local service of central government & 292 & $4.2 \%$ & 9 & $0.0 \%$ \\
Local government & 4,248 & $61.4 \%$ & & 131,000 & $81.0 \%$ \\
Management of state-owned land & 13 & $0.2 \%$ & & 117 & $0.1 \%$ \\
Education-related entities & 2 & $0.0 \%$ & & 31 & $0.0 \%$ \\
Hospital \& other healthcare & 971 & $14.0 \%$ & & 23,000 & $14.2 \%$ \\
Public housing & 13 & $0.2 \%$ & 3,562 & $1.4 \%$ \\
Other public entities & 1,196 & $17.3 \%$ & & 3,561 & $2.2 \%$ \\
\hline Total & 6,922 & & 162,000 &
\end{tabular}

This table reports the average breakdown of bank debt in the credit registry over the period 2007-2017. Local government includes communes, départements, régions, and $\mathrm{EPCl}$.

sions. In particular, the loans taken by local public entities are not subject to the French Public Procurement Code (Code des Marchés Publics). The reason is that a 2005 decree specifically excluded this market from the competitive procedure imposed by EU procurement rules, allowing politicians to choose-without any regulatory supervision-which banks to deal with.

The only legal constraint is on the amount that politicians can borrow. A local government is required by law to balance its budget. Thus local governments may borrow funds only to finance their investments, not their current spending, and must use their own resources to repay capital and the interest on debt. This is the so-called "golden rule".

This market is profitable for banks, since the interest rates paid by local public entities on these loans are significantly higher than justified by their risk. French law (the law of 25 January 1985, now the Commercial Code) prevents local public entities from going bankrupt or undergoing liquidation proceedings. If a local public entity has difficulty repaying, it is placed under the central government's supervision. So as long as the French government does not default, the creditors of a public entity can be sure that their claims will be repaid 10

\footnotetext{
${ }^{10}$ It is interesting that this feature has been recognized by the Court of Justice of the European Union as a breach of EU competition law, since French local public entities operating in competitive markets can-thanks to the French government's implicit guarantee-obtain financing at a cost lower than their rivals. In this case, the European
} 
Given the existence of this explicit government guarantee, interest rates should reflect the likelihood of the French government defaulting; hence they should converge toward the interest rate on French government bonds (plus some "processing costs"). Yet that is far from the case. We estimate the spread paid by local public entities over the rates of Treasury bills with similar maturities - not only in the time series (left panel of Figure 1) but also in the cross section (right panel of the figure).11 We find that, during the sample period considered, a large fraction of loans to local public entities (i.e., those for which we can observe the interest rate) pay a spread of 150-200 basis points.

It is possible that this spread is an upper bound. Indeed central government debt has a risk weight of zero since Bale II, while it might be higher for local public entity debt. After a careful analysis of the different banks' annual reports, we find that the risk weight is between zero and twenty percent. Assuming an upper bound of twenty percent for all banks, it implies the cost for banks to finance one additional euro of loans to public entities is: $0.2 \times$ cost of equity + [1-(0.2 $\times$ cost of equity $)] \times$ cost of debt. The average cost equity for French banks in 2013 was $8 \%$. In addition, since 2015, the "large systemic banks" have additional cost of capital due to prudential ratios. If we have very conservative and assume that all loans to public entities are issued by these banks, this gives us a maximum value for the cost of equity of $13.5 \% \times 8 \%$. Taking an estimate for the cost of debt of $3.2 \%$, we get that the total cost for banks to finance an additional euro of loans to public entities is: $0.2 \times 13.5 \% \times 8 \%+(1-13.5 \% \times 0.20) \times 3.32 \%=$ $3.44 \%$. If banks decide to grant one additional euro of loans to the central government, it can entirely finance it via debt since the risk weight is zero. The total cost is therefore $3.32 \%$. This implies that even in the most conservative estimate for both capital requirement and cost of capital, the gap in the price between a loan to the central government and local public entities

Commission noted that "[t]he procedures described above imply that the State performs the role of guarantor of last resort. It may therefore be legitimately concluded that La Poste benefits from an unlimited guarantee on the part of the French State because of its legal form as a publicly owned establishment." (Decision 2010/605/EU of 26 January 2010)

${ }^{11}$ We restrict the analysis to loans with fixed rates. For maturities that are not traded, we use monthly data to derive a linear interpolation. 


\section{Figure 1 - Spread of Local Public Entity Debt over Treasury Bonds}
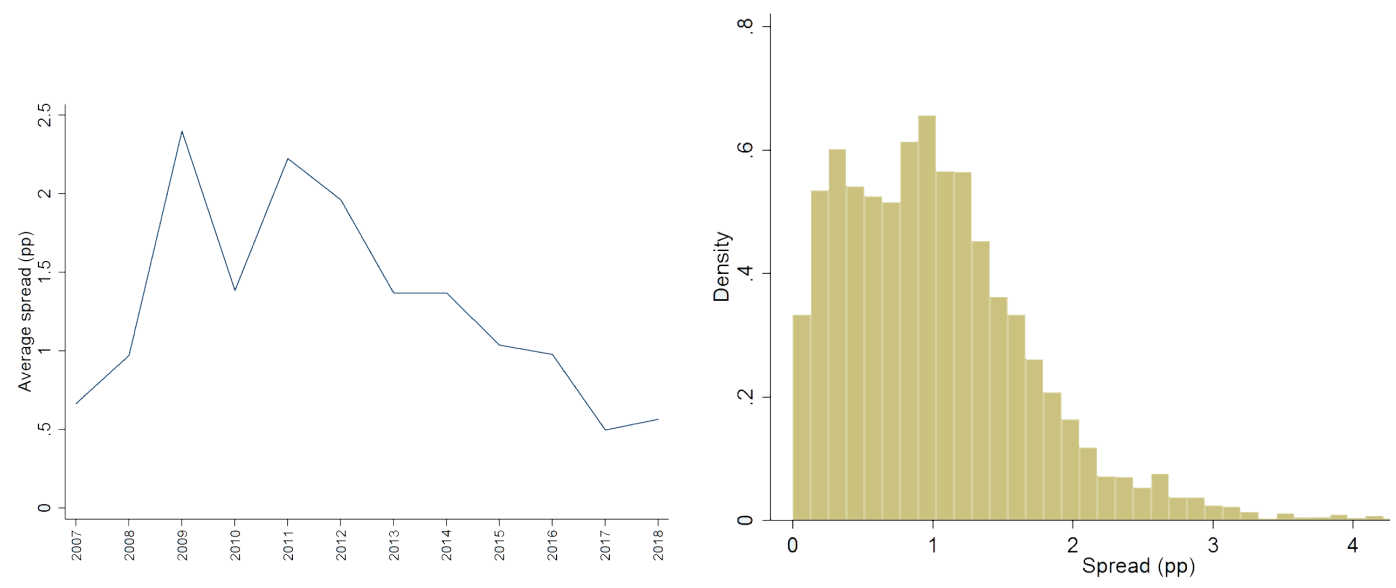

This figure shows the spread of local public entity debt relative to Treasury bonds of similar maturities in the time series (left panel) and in the cross section (right panel).

should be around $0.15 \%$, to be compared with the gap we found of $1.5 \%$ to $2 \%$. As such, differences in capital requirement and risk-weighting cannot explain the spread we document and still implies that loans to local public entities are highly profitable.

Why doesn't the competition among lenders drive interest rates down to the rate on government bonds? Although answering that question would require expanding the scope of this paper, we offer three potential explanations. First, the French banking sector has experienced a continuous trend of concentration that accelerated during the mid-2000s, reducing competition among the major lenders (Fraisse, Hombert, and Lé (2018)). Second, local public entities are not set up to maximize profits and so are likely less motivated (than are private firms) to reduce prices via competition. Third, if these high interest rates are part of a two-way gift exchange mechanism then politicians have no reason to reduce them, since those rates are simply the price of being able to induce banks to extend credit to the local economy in election periods. ${ }^{12}$

\footnotetext{
${ }^{12}$ Local public debt can be used by French politicians as a way to increase their reelection chances because, in part, voters do not fully understand the consequences of public indebtedness. This phenomenon is explored by Pérignon and Vallée (2017).
} 


\section{Reciprocal favors: A conceptual framework}

Before turning to our empirical analysis, it is useful to review the logic of reciprocal favors and the conditions under which such an equilibrium can exist. This conceptual framework will then guide our empirical analysis.

Politicians and banks can engage in a game of exchanging favors. During the pre-election period, banks can bestow economic favors on the politician to aid her reelection. At the end of this period, an election takes place. If the incumbent is reelected, then she can reciprocate the favor; if she is not reelected, the relationship ends. In this repeated game, the favors are informal and contractual agreements are not possible.

Politicians face partially myopic voters, who are willing to punish incumbents for poor recent macroeconomic performance (Weatherford (1978)) or local credit contraction (Antoniades and Calomiris (2018)). As a result, the prospects of an incumbent seeking reelection depend on the state of the local economy-in particular, on the supply of credit to local firms.

Under these circumstances, a politician can request an election favor from the bank during election years in the form of supplying more credit to the private sector than the bank would otherwise have supplied. This favor then increases the politician's chances of being reelected, and its value depends on two factors: the incumbent's likelihood of losing the election and the election's proximity. Note that if the election is contested then a politician benefits from any increase in the supply of credit to the local economy-especially during an election year, when the effect of local economic conditions on voter choices is the greatest.

What, then, prevents all politicians from working continuously to expand credit within the local economy? For the bank to participate in the reciprocal favors game, politicians must return the bank's favor by directing at least some public entity loans to the bank. This requirement amounts to a private cost for the politician that is equal to the distortion of the optimal allocation of 
public entity debt across lenders. ${ }^{13}$ So in order to minimize her costs, the politician seeks help from the bank only for the minimum number of years and only if the election is contested.

From the bank's perspective, the favor is an input meant to influence the politician and ultimately gain access to the market for public entity debt. This input has a cost that depends on the magnitude of the distortion relative to the optimal credit allocation (i.e., absent the reciprocal favors mechanism). We can therefore expect that profit-maximizing banks will have only limited leeway to engage in such activities and thereby to minimize this cost.

Considering that this input is costly for the bank, we should also expect these "political favors" to be granted selectively when the input is most productive, or in situations where it can provide large gains - namely, when the politician has considerable influence over the allocation of public entity debt. In this framework, granting a favor is costly for all agents, and it occurs only if they believe that the favor will be reciprocated. These considerations yield three empirical predictions.

First, an incumbent politician will ask for favors only when she is highly vulnerable, as when she faces a rapidly approaching contested election. Second, a bank will grant politicians favors only when its expected gains are large, which occurs when (a) the incumbent is powerful enough to affect the allocation of public entity loans and (b) the bank is willing to access the public entity loan market.14

Third, the banks that contributed to a reelection campaign should be observed to receive additional public entity loans if the local politician is actually reelected. When such a relationship ends

\footnotetext{
${ }^{13}$ More precisely, this cost is most strongly associated with the following three factors. (i) Political capital depletion: for a public entity to take up a loan, the MP must spend political capital to convince those who directly control that public entity as well as the government agents in charge of controlling the debt of local public entities. (ii) Budget profligacy: too large of an increase in the indebtedness of local public entities in the MP's constituency may increase the critical attention of civil society. (iii) Reputation cost: playing this game on a larger scale increases the probability of being discovered, which would result in large reputations costs.

${ }^{14}$ There may be variation in the willingness or ability of banks to participate in this market. Such variation may result either from the banks' characteristics or from their past participation in a reciprocal favors game- that is, since the condition to continue with a reciprocal favors strategy is less stringent than that to be the first player who grants a favor. It is intuitive that agents develop a reputation for "agreeing to play the reciprocal favors game", which renders them more likely to grant each other favors if they have played in the past.
} 
because the incumbent is not reelected, we can expect the newly elected politician to refrain from immediately restarting the reciprocal favors equilibrium with her predecessor's partnersespecially if she is inclined to punish those banks.

\section{Data}

\subsection{Credit data and descriptive statistics}

Our main data set derives from the French Credit Registry, which is administered by the Bank of France, collecting data on corporate borrowers that have total exposure (debt and guarantees) of more than $€ 25,000$ with financial intermediaries operating in France. For each bank-firm pair, we recover the end-of-month total outstanding credit granted (whether drawn or undrawn) for each month from January 2007 to March 2017; thus we obtain a monthly average of 3 million bank-firm observations. The French Credit Registry covers loans granted to private firms as well as loans to such local public entities as local governments, state-owned enterprises, and public hospitals. The data provide information on all different types of credit, which we aggregate into two groups: short-term credit and medium/long-term credit. Since our analysis focuses on private banks, it excludes all government-owned banks. ${ }^{15}$ All our analyses also exclude interbank lending. ${ }^{16}$ Finally, we exclude loans to real estate investment trusts, which often are corporations owned by households to benefit from preferential tax treatment when investing in real estate. We are left with about 2.2 million bank-firm observations per month on average.

Recall from Section 3 that our approach relies on distinguishing among banks in terms of their willingness to participate in the market for loans to local public entities. We start investigating

\footnotetext{
${ }^{15}$ There are 21 government-owned banks in France, of which 19 are "municipal savings" banks (local establishments that specialize in pawnbroking).

${ }^{16}$ Interbank lending accounts for a large share of credit volumes (about a third of short-term credit). It consists primarily of loans between banks from the same banking group and so does not adequately reflect economic activity in the private sector.
} 
this dimension by examining banks' actual participation in that market. For each bank, we compute the average share of loans to local public entities in their total portfolio over the sample period. The distribution is skewed rightward: $75 \%$ of our sample's banks have balance sheets that include no loans to local public entities.

We continue our exploration by sorting banks according to the share of loans to local governments in their portfolio and then looking at bank characteristics. In view of the right-skewed distribution just described, we split banks into four groups: the first group includes only those banks that do not lend to local governments, and the three remaining groups are defined by taking the terciles of the distribution's positive support.

Table 2 reports summary statistics for the characteristics of these different types of banks. Two facts are worth noticing. First, most foreign banks are in the group that do not lend to local public entities, which conforms with the idea that being active on the local public entity debt market requires a certain degree of local connection. Second, the share of cooperative banks is increasing in the share of loans to local public entities in the banks' portfolio.17 Because cooperative banks feature a high degree of autonomy compared to traditional banks thanks to diffuse share ownership and tend to traditionally accumulate substantial reserves, their managers have more autonomy than those at traditional banks. In addition, the local nature of cooperative banks makes them likely to maintain long-standing relationships with local politicians.

We discussed previously how the reciprocal favors game is more easily sustained when the same participants have already played before. In the same vein, we find that_-among all banks involved in the market for public entity loans in a constituency at time $t-97.7 \%$ of them were already involved in this market (and in that same constituency) at time $t-1$.

\footnotetext{
${ }_{17}$ The defining characteristics of a cooperative bank are that its capital is owned (in the form of shares) by the cooperative's members and that those members are also the bank's customers. These shares confer fewer rights than does corporate stock; moreover, they cannot be traded on the open market and can be repurchased by the bank only at their nominal value and subject to certain conditions. In addition, French cooperative banks have traditionally been set up as networks that comprise a hierarchy of legally independent entities-for instance, local banks owned by members, regional banks owned by the local banks, and a federal or national body owned by the regional banks. The decision-making process then reflects this "inverted pyramid" structure.
} 
Table 2 - Characteristics of Bank Type

\begin{tabular}{lrrrrr}
\hline \hline Bank type \#banks & $\begin{array}{c}\text { Mean sh. } \\
\text { lending to } \\
\text { local public entities }\end{array}$ & \#cities & $\begin{array}{c}\text { Share of entities } \\
\text { owned by foreign groups }\end{array}$ & $\begin{array}{c}\text { Share of } \\
\text { cooperative } \\
\text { banks }\end{array}$ \\
\hline No lending & 459 & $0.0 \%$ & 338 & $41 \%(17 \%)$ & $3 \%$ \\
1st tercile & 73 & $0.3 \%$ & 2,121 & $26 \%(5 \%)$ & $11 \%$ \\
2nd tercile & 72 & $9.3 \%$ & 1,897 & $14 \%(1 \%)$ & $58 \%$ \\
3rd tercile & 72 & $45.8 \%$ & 1,698 & $6 \%(3 \%)$ & $76 \%$ \\
\hline
\end{tabular}

This table reports the main characteristics of the banks in our sample as a function of their respective balance sheet's levels of lending to public entities. The 1st, 2nd, and 3rd terciles are defined on the support of positive distribution. The sample period is from 2007 to 2017 inclusive. Our study includes 555 distinct constituencies between 2007 and 2012 and 539 distinct constituencies afterwards. All variables are Winsorized at the 1\% level in each tail.

We are thus led to identify a bank's willingness or ability to participate in the market for public entity loans by the presence of public entity debt on its balance sheet. For that purpose we create an indicator variable Involved_bank ${ }_{b}$ that is set equal to 1 if bank $b$ has previously lent to local public entities (and is set to 0 otherwise).

We construct our main data set by transforming monthly data into quarterly data and then summing credit at the constituency $\times$ quarter or at the constituency $\times$ quarter $\times$ bank-type level ${ }^{18}$ Table 3 presents summary statistics of our credit-related variables by constituency.

Table 3 - Summary Statistics of Economic Variables by Constituency

\begin{tabular}{lccccc}
\hline Variable & Mean & Std. Dev & p25 & p50 & p75 \\
\hline Short-term credit (€ thousands) & 238,661 & 414,427 & 85,679 & 134,455 & 240,466 \\
Total credit (€ thousands) & 474,681 & 592,651 & 151,798 & 242,073 & 528,096 \\
Number of banks & 145 & 44 & 116 & 136 & 164 \\
Number of involved banks & 82 & 23 & 67 & 79 & 93 \\
Employment & 56,503 & 30,442 & 39,664 & 49,539 & 61,439 \\
\hline
\end{tabular}

This table reports summary statistics for the main variables used in our study. For each variable we present its mean, standard deviation (S.D.), 25th percentile (p25), median (p50), and 75th percentile (p75). The sample period is from 2007 to 2017. Our study includes 555 distinct constituencies between 2007 and 2012 and 539 thereafter. All variables are Winsorized at the $1 \%$ level in each tail.

\footnotetext{
${ }^{18}$ In most of our analyses, "bank-type" simply indicates whether (or not) the focal bank's portfolio includes local public entity loans, which we call "involved banks".
} 


\subsection{Political variables}

We need two types of information about politicians. First: Is the incumbent facing a contested election? Second: Can the incumbent affect the allocation of credit to local public entities?

Answering these questions required that we assemble a unique data set on French local political life. Our first source of information is data on parliamentary elections for the elections held in 1993, 1997, 2002, 2007, and 2017. These data were obtained from the French Home Affairs Office (Ministère de l'Intérieur) and Sciences Po (Centre de Donnés Socio-Politiques ). We collect information on all candidates' names, political parties, and votes received. Although we focus on the parliamentary election cycle, we account for the incentives of MPs who also hold the position of mayor. We therefore collect data (from the same sources) on municipal elections 19

The resulting data set allows us to construct three political variables at the constituency-quarter level. Details on the construction of these variables are given in the Appendix. See Table 4 for the summary statistics.

First we create a binary variable, Election_year ${ }_{c, t}$ set to 1 only if a parliamentary election is held in constituency $c(a)$ during year $t$ or (b) in the year of a municipal election in which the incumbent MP is also running (about $25 \%$ of MPs).

Second, we indicate whether the incumbent faces a contested election via the dummy variable Contested $_{c, t}$; this dummy is set to 1 only if the incumbent is (a) running in a constituency that is not a stronghold for her party or (b) competing in a close election. We flag a constituency as not being a "stronghold" if, prior to the incumbent's election, the constituency was held by

\footnotetext{
${ }^{19}$ Thus we collect data for the 1995, 2001, 2007, and 2014 municipal elections. For elections held after 2001, we obtain the names of all the candidates on the ticket (called "lists" in France), the names of all members on each list, the list's party affiliation, and the score of the list. For the years preceding 2001, we have only the score of the lists and their political affiliation. The mayor is elected indirectly (by the municipal council) and so need not head up the winning list. We therefore use different data from the Home Affairs Office-namely, the Registre National des Elus, which provides the names of mayors.
} 
Table 4 - Summary Statistics of Political Variables

\begin{tabular}{lcccc}
\hline Variable & 2007 & 2012 & 2017 & Total \\
\hline Powerful_MP & 0.34 & 0.34 & 0.30 & 0.33 \\
Political longevity & 0.24 & 0.25 & 0.26 & 0.25 \\
Former minister & 0.17 & 0.19 & 0.13 & 0.16 \\
Central government support & 0.62 & 0.55 & 0.48 & 0.55 \\
Regional government support & 0.33 & 0.39 & 0.57 & 0.43 \\
Mayors' support & 0.03 & 0.37 & 0.31 & 0.24 \\
Contested_election & 0.58 & 0.50 & 0.79 & 0.62 \\
Not party stronghold & 0.48 & 0.20 & 0.34 & 0.34 \\
Upcoming contested election & 0.26 & 0.38 & 0.71 & 0.44 \\
\hline
\end{tabular}

This table reports summary statistics for our political variables. Because they are all indicator variables, we present only their means. The construction of variables is described in the Appendix. The sample period is from 2007 to 2017 ; we have 555 distinct constituencies between 2007 and 2012 and 539 thereafter.

another party. ${ }^{20}$ We consider the upcoming election to be a close if, based on subsequent actual election results, the number of votes for an incumbent MP differs by less than $6 \%$ from the number for her closest rival.21

Third, we use two criteria to assess an MP's influence over the allocation of public entity loans: her influence in the party and her direct connections with other elected local politicians of the same party. Being a prominent political figure matters because, in order to reciprocate a favor, the MP must convince other politicians to allocate the debt of the local public entities they oversee to specific banks; that task is easier if the incumbent is powerful in her own party, since her endorsement is sought by local politicians. Being politically connected matters because it increases the number of other politicians whom a powerful MP could convince. We consider an MP to be "influential" if he (a) has been elected to the House of Representatives at least three times since 1993 or (b) has ever been a minister of the Fifth Republic. Our proxy for the number of local connections is based on whether the incumbent is from the same party as the national government or the regional council and on whether more than 50\% of the mayors in an MP's

\footnotetext{
${ }^{20}$ For similar proxies of contested elections, see Bertrand, Kramarz, Schoar, and Thesmar (2018) in the case of France and Fishback, Haines, and Kantor (2007) for the United States.

${ }^{21}$ Results are robust to winning margins that range from $2 \%$ to $14 \%$.
} 
Figure 2 - Contested Constituencies of Powerful Politicians
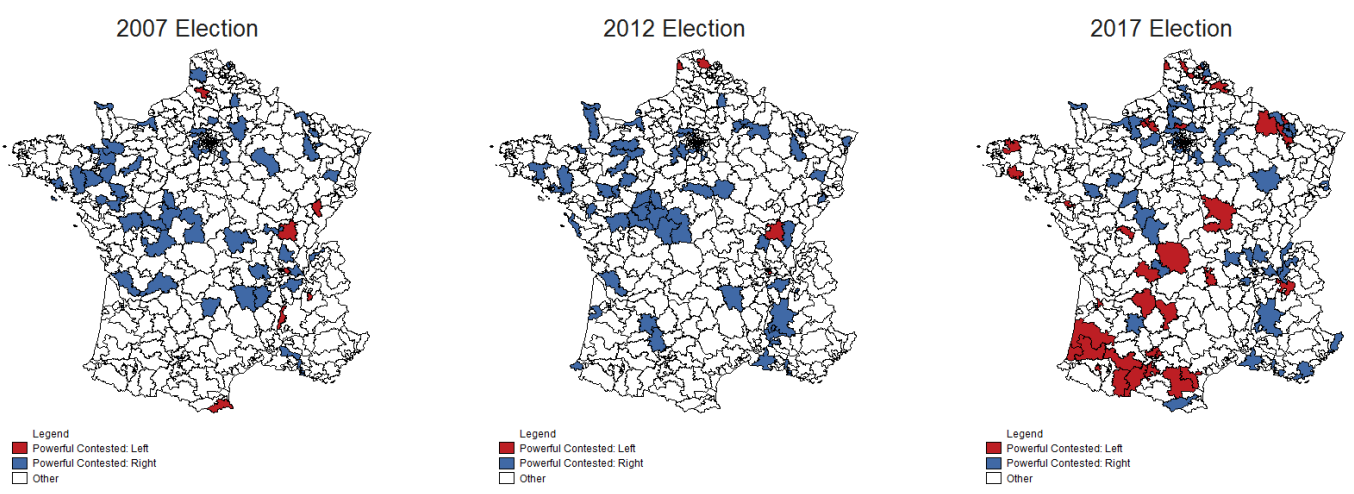

This figure shows the location of contested constituencies of powerful politicians (MPs) for the three elections in our sample. A constituency is contested if it was held by another party in the previous election or if, in the next election, the number of votes received by the political incumbent and her closest rival differs by less than $6 \%$. Politicians are powerful if they are prominent figures in their party and have direct connections with other elected local politicians.

constituency belong to the same party. ${ }^{22}$ We create the indicator variable Powerful_ $M P_{c, t}$, which is set to 1 only if the incumbent is both influential and locally connected. ${ }^{23}$

Figure 2 illustrates - for the three parliamentary elections in our sample - the geographic distribution of powerful MPs facing a contested election. It is reassuring from our research perspective that no clear geographic patterns emerge and that contested constituencies are widespread across France.

\section{Do private banks aid the reelection of politicians?}

\subsection{Empirical identification}

We begin the empirical analysis by testing whether we can identify a political credit cycle for private banks. Our identification strategy closely follows the theoretical predictions of Section 3 . Hence we conjecture that politically motivated distortions in lending decisions are (a) greater

\footnotetext{
${ }^{22}$ We obtain similar results when using either a $40 \%$ or a $60 \%$ cutoff.

${ }^{23}$ We experiment with alternative ways of identifying powerful MPs and obtain consistent results across definitions.
} 
in areas that are politically more contested in the year of the election and (b) concentrated in constituencies where the incumbent has future influence over the allocation of local public entity debt.

Formally, we estimate the following equation:

$$
\begin{aligned}
\text { Credit }_{c, t}= & \beta \text { Election_year }_{t} \times \text { Contested }_{c, t} \times \text { Powerful_MP }_{c, t} \\
& + \text { Constituency_characteristics }_{c, t} \otimes \text { Election_year }_{t} \\
& +\theta_{c}+\delta_{r, t}+\varepsilon_{c, t}
\end{aligned}
$$

Credit $_{c, t}$ is the (logged) volume of credit extended by all banks to private firms in constituency $c$ at time $t$. Recall from Section 4 that Powerful_ $M P_{c, t}$, Contested ${ }_{c, t}$, and Election_year ${ }_{c, t}$ are dummies set equal to 1 only if (respectively) the incumbent is powerful, the election is contested, and the election is held this year (while including municipal elections). We use $\otimes$ to denote the cross interaction among the different variables; hence the term Constituency_characteristics ${ }_{c, t} \otimes$ Election_year ${ }_{t}$ allows for each combination of constituency characteristics - namely, Contested ${ }_{c, t}$ and Powerful_ $M P_{c, t}$ with each other and with the variable Election_year ${ }_{t}$ as well as all combinations of the single terms Contested $c, t$, Powerful_MP ${ }_{c, t}$, and Election_year ${ }_{t}$.

The term $\theta_{c}$ captures constituency fixed effects and ensures that our regressions are not affected by any time-invariant heterogeneity across constituencies. We use $\delta_{r, t}$ to denote region $\times$ time fixed effects and also to control for time-varying unobserved heterogeneity across French regions-for example, differences in regional business cycles and divergence in political voting patterns that may be correlated with credit supply. ${ }^{24}$ In particular, our use of region $\times$ time fixed effects forces the parameter of interest, $\beta$, to be identified solely by comparing constituencies within the same region and as such precludes comparisons across regions. Standard errors are clustered at the constituency level to account for possible autocorrelation in the error term.

\footnotetext{
${ }^{24} \mathrm{~A}$ reform effective 1 January 2016 reduced the number of metropolitan regions from 22 to 13 . We use the current (post-reform) definition of the regions throughout our sample.
} 
This regression's coefficient of interest is $\beta$, which measures the difference in credit volumesduring an election year involving contested constituencies-when the incumbent MP is not versus is powerful in terms of affecting the allocation of local public entity debt. By comparing the supply of credit within contested constituencies yet across MPs with various degree of influence, our specification controls for the average effect of being a contested constituency (i.e., for Election_year ${ }_{t} \times$ Contested $\left._{c, t}\right)$ and therefore is valid under milder identification assumptions. In particular, it controls for the possibility that constituencies with contested elections exhibit different economic trends than those with non-contested elections-a control we require because a sluggish economy may be the exact reason why some constituencies are contested.

Our framework of quid pro quo yields one additional prediction that we exploit later in the empirical analysis: private banks should be more willing to extend credit in election years when the value of currying favor with political clients is high, which it will be if banks can then more easily access the market for public entity debt. As explained in Section 4, we proxy banks' willingness to enter this market by considering banks whose portfolios already hold loans to local public entities and we augment equation (1) by interacting all our variables with the dummy Involved_bank ${ }_{b}$ (which equals 1 if bank $b$ has ever extended loans to local public entities and otherwise equals 0 ).

The variable of interest in this case is the interaction between Involved_bank ${ }_{b}$ and Election_year ${ }_{t} \times$ Contested $_{c, t} \times$ Powerful__ $M P_{c, t}$, which exploits variations within constituency-year as well as across banks with and without public entity debt on their respective balance sheets. This interaction's coefficient is estimated by comparing the change in credit volumes-during an election year involving contested constituencies and an influential incumbent-for banks that did versus did not (in the same constituency and in the same year) extend credit to local public entities. In order to ease the exposition, we report results only for the relevant interaction variable. However, each regression incorporates all single and interacted terms. 


\subsection{Results}

The results of estimating equation (1) are reported in Table 5. In column [1] we start with the interaction Contested $\times$ Election_year and find no material difference in the volume of credit between contested and non-contested elections in the run-up to an election. This result alone suggests that preventing a politically induced credit cycle requires only that banks with a corporate governance be formally insulated from politicians.

Table 5 - Political Credit Cycle for Private Banks

\begin{tabular}{|c|c|c|c|c|}
\hline \multirow[t]{2}{*}{ Dependent variable: } & \multicolumn{3}{|c|}{ Short-term credit } & \multirow{2}{*}{$\begin{array}{c}\begin{array}{c}\text { Total } \\
\text { credit }\end{array} \\
{[4]}\end{array}$} \\
\hline & {$[1]$} & [2] & [3] & \\
\hline Contested $\times$ Election_year $\times$ Powerful_MP & & $\begin{array}{c}.086 * * * \\
(.043)\end{array}$ & $\begin{array}{c}.093 * * * \\
(.044)\end{array}$ & $\begin{array}{l}.085^{*} \\
(.048)\end{array}$ \\
\hline \multirow[t]{2}{*}{ Contested $\times$ Election_year } & .018 & .01 & .00 & .019 \\
\hline & $(.014)$ & $(.01)$ & $(.01)$ & $(.016)$ \\
\hline Interacted terms & $\checkmark$ & $\checkmark$ & $\checkmark$ & $\checkmark$ \\
\hline Constituencies FE & $\checkmark$ & $\checkmark$ & $\checkmark$ & $\checkmark$ \\
\hline Time FE & $\checkmark$ & $\checkmark$ & - & - \\
\hline Region $\times$ Time FE & - & - & $\checkmark$ & $\checkmark$ \\
\hline Observations & 24,671 & 24,671 & 24,671 & 24,671 \\
\hline
\end{tabular}

Dependent variables are the (log of) short-term and total loans to private companies (quarterly frequency). When the incumbent is also a mayor, we account for the municipal election cycle. A constituency is contested if it was held by another party in the previous election or if that actual election result (between the incumbent MP and her closest rival) was decided by less than $6 \%$. An MP is powerful if she is a prominent figure in her party and has direct connections with other elected local politicians. FE = fixed effects. Standard errors (in parentheses) are clustered by constituency. $*, * *$, and $* * *$ indicate significance at (respectively) the $10 \%, 5 \%$, and $1 \%$ levels.

However, a different story emerges when we look at contested constituencies where the incumbent MP is influential. Indeed, interacting Contested $\times$ Election_year with Powerful_MP $(=1$ if the MP is influential) reveals that the interaction term is both positive and statistically significant at the $1 \%$ level (column [2]). In terms of economic magnitude, private firms in contested constituencies where the MP is influential benefit from an election-year volume of loans that is 8.6\% larger than in similarly contested constituencies in which the MP is not powerful. As shown 
in column [3] of the table, this magnitude increases slightly when the regressions incorporate region $\times$ time fixed effects - that is, to account for the possibility of differential trends across regions.

Our results so far remain silent with regard to which type of future benefits banks hope to receive in return. Note, in addition, that these results could be driven by only powerful incumbents being able to implement demand-side policies (e.g. a fiscal stimulus) to boost the local economy and improve their prospects in an upcoming contested election. In this case, the volume of credit would increase not because banks are granting a favor to politicians (the supply-side account) but because the corporate sector's demand for credit increases as a result of those stimulus policies.

We address this endogeneity issue - and begin to explore how the bank benefits from extending credit in contested constituencies-by exploiting another source of variation across banks: the presence of public entity debt in their loan portfolios. This additional variation allows us to augment our specification with constituency $\times$ time fixed effects and also to identify the outcome of interest, within a constituency-time cell, across banks that do or do not lend to local public entities. The inclusion of constituency $\times$ time fixed effects controls for unobserved time-varying characteristics at the constituency level-for instance, the possible implementations of different type of local policies, differences in economic conditions that could affect local demand for credit, and heightened political uncertainty due to powerful incumbents being challenged-that might have a direct effect on firm investment (Julio and Yook (2012)) or bank lending (Kara and Yook (2019)). ${ }^{25}$ Within this framework, our identifying assumption is that the variations in credit that stem from changes in local credit demand (e.g., due to demand-side policies) affect both types of banks similarly. In contrast, variations in credit that arise through the reciprocal favors channel should be concentrated on banks that have previously lent to local public entities.

Adding this source of variation also allows us to include bank-type $\times$ time fixed effects (to

\footnotetext{
${ }^{25}$ In this case we no longer include region $\times$ time fixed effects because each constituency belongs to one region. Therefore, region $\times$ time fixed effects are collinear with constituency $\times$ time fixed effects.
} 
remove unobserved time-varying shocks at the bank level) and bank-type $\times$ constituency fixed effects (to account for possible assortative matching between banks and constituencies). By comparing credit volumes within bank-type-time cells-and across constituencies in which we are likely versus unlikely to observe election favors - this specification rules out that our results are driven by banks in different constituencies being exposed to different shocks or by banks selecting themselves into specific constituencies. Hence it controls also for the possibilities that banks are not allocated randomly across constituencies and that (positive) bank-specific shocks are correlated with constituencies where elections are contested and the incumbent is powerful.

In sum, our exogeneity condition would be violated only if there were shocks correlated with credit volumes that are: (a) specific to election years, (b) occurred only in constituencies featuring an influential incumbent who faces a contested election, and (c) affected only those banks that participated in the market for loans to local public entities. Yet it seems unlikely that any shock would satisfy all of these conditions.

Table 6 presents our findings for the allocation of credit across bank types. Column [1] shows that, even during an election year, banks that have no public entity debt on their balance sheet have the same lending policies in constituencies where a powerful incumbent faces a contested election as in other constituencies. This result should alleviate any concern that our results are explained by changes in credit demand and not credit supply.

Column [2] in Table 6 reports the results when we instead focus on the subsample of banks with public entity loans on their balance sheets. We find that these banks, which are a priori more prone to granting election favors, increase their supply of credit by $13.9 \%$ during an election year. We assess whether the difference between the two bank types is statistically significant by using the dummy Involved_bank (defined in Section 5.1) and create a panel at the constituency-bank-type-time level. Columns [3]-[5] present our results, which establish that the difference between the two type of banks is statistically significant at the $1 \%$ level. In comparison with banks not involved in the public entity loan market, banks that are involved 
Table 6 - Political Credit Cycle and the Role of Involved Banks

\begin{tabular}{|c|c|c|c|c|c|}
\hline \multirow{2}{*}{$\begin{array}{l}\text { Dependent variable: } \\
\text { Sample }\end{array}$} & \multicolumn{4}{|c|}{ Short-term credit } & \multirow{2}{*}{$\begin{array}{c}\begin{array}{c}\text { Total } \\
\text { credit }\end{array} \\
\text { All } \\
{[5]}\end{array}$} \\
\hline & $\begin{array}{c}\text { Not } \\
\text { involved } \\
{[1]}\end{array}$ & $\begin{array}{l}\text { Involved } \\
\text { [2] }\end{array}$ & $\begin{array}{l}\text { All } \\
{[3]}\end{array}$ & $\begin{array}{l}\text { All } \\
{[4]}\end{array}$ & \\
\hline Contested $\times$ Election_year $\times$ Powerful_ $M P$ & $\begin{array}{l}-.001 \\
(.065)\end{array}$ & $\begin{array}{l}.139 * * * \\
(.048)\end{array}$ & $\begin{array}{l}-.001 \\
(.06)\end{array}$ & - & - \\
\hline Contested $\times$ Election_year $\times$ Powerful_MP & & & $.141^{* * *}$ & $.142 * * *$ & $.079 * * *$ \\
\hline$\times$ Involved_bank & & & $(.01)$ & $(.016)$ & $(.030)$ \\
\hline Interacted terms & $\checkmark$ & $\checkmark$ & $\checkmark$ & $\checkmark$ & $\checkmark$ \\
\hline Constituencies $\times$ Bank-type FE & $\checkmark$ & $\checkmark$ & $\checkmark$ & $\checkmark$ & \\
\hline Region $\times$ Time FE & $\checkmark$ & $\checkmark$ & $\checkmark$ & $\checkmark$ & $\checkmark$ \\
\hline Bank $\times$ Time FE & - & - & $\checkmark$ & $\checkmark$ & $\checkmark$ \\
\hline Constituencies $\times$ Time FE & - & - & - & $\checkmark$ & $\checkmark$ \\
\hline Observations & 24,671 & 24,671 & 49,336 & 49,336 & 49,336 \\
\hline
\end{tabular}

Dependent variables are the (log of) short-term and total loans to private companies (quarterly frequency). When the incumbent is also a mayor, we account for the municipal election cycle. A constituency is contested if it was held by another party in the previous election or if that actual election result (between the incumbent MP and her closest rival) was decided by less than $6 \%$. Members of parliament are powerful if they are prominent figures in their party and have direct connections with other elected local politicians. The Involved bank variable is an indicator set equal to 1 if the bank has positive local public entity debt on its balance sheet (and set to 0 otherwise). FE $=$ fixed effects. Standard errors (in parentheses) are clustered by constituency.

$*, * *$, and $* * *$ indicate significance at (respectively) the $10 \%, 5 \%$, and $1 \%$ levels

increase their volume of credit by $14.1 \%$ during election years in constituencies where a powerful incumbent is contested. Column [3] controls for bank-type $\times$ time fixed effects to account for possible bank-specific shocks that might affect the supply of credit. In column [4] (our preferred specification) we include constituency $\times$ time fixed effects to control for local demand shocks. In this case, the coefficient of interest is estimated by comparing-for the same constituency and at the same time - the credit volume of banks involved and not involved in the public entity loan market. 26 We derive a similar point estimate, which is consistent with our previous result that differences in local demand effects are unlikely to be a decisive factor in this setting.

The coefficient on long-term credit (column [5]) is lower than for short-term credit but still positive and highly significant, consistent with the idea that banks only need to boost local

\footnotetext{
${ }^{26}$ The coefficient for Contested $\times$ Election_year $\times$ Powerful_MP is not identified here because this interaction term varies only at the constituency-time level and thus is absorbed by the constituency $\times$ time fixed effects.
} 
credit around the election. Indeed, credit granted for a period longer than one year would not increase more the political incumbent chances to be reelected.

\subsection{Tracing out politically driven credit}

Which types of firms most benefit from the increased credit supply described here? In order to answer this question, we first leverage the credit registry's inclusion of firms' balance sheet data from administrative tax-files; these data allow us to compute various time-invariant proxies at the 2-digit industry level by using the mean sample value. 27 Then we focus on two characteristics of an industry-its need for short-term liquidity and its economic dynamism-and devise two proxies for each characteristic. For short-term liquidity needs, we calculate the ratio of working capital needed (based on sales receipts and required interest payments) to the wealth, or valueadded, produced by the firm. For economic dynamism we use the firm's productivity (ratio of value-added to total assets) and the likelihood of bankruptcy, defined as the industry's number of bankruptcy-filing firms divided by its total number of firms. We next split the sample in two (based on its mean or median value) to identify "high" and "low" industries for our various proxies.

So that we can easily test whether certain sectors enjoy more politically driven credit, we expand the sample at the industry-constituency-bank-type level and estimate equation (1) separately for our low and high subsamples of industries. We also report the difference between low and high and and the statistical significance of that value.

Table 7 gives our results. In accordance with the notion that politically motivated credit is used to boost short-term outcomes just before an election, we find that this credit is extended only to firms with high liquidity needs to finance their working capital (column [2]) or their current interest repayment (column [4]). In either case, the difference between industries that are versus are not highly dependent on short-term financing is statistically significant at the $5 \%$ level for working capital and at the $1 \%$ level for interest repayments.

\footnotetext{
${ }^{27}$ There are 62 distinct industries at the 2-digit level in France.
} 
Table 7 - Firms Benefiting from Politically Driven Credit

\begin{tabular}{|c|c|c|c|c|c|c|c|c|}
\hline \multirow{3}{*}{$\begin{array}{l}\text { Industry characteristics: } \\
\text { Proxy } \\
\text { Sample }\end{array}$} & \multicolumn{4}{|c|}{ ST liquidity needs } & \multicolumn{4}{|c|}{ Declining industries } \\
\hline & \multicolumn{2}{|c|}{$\begin{array}{l}\text { Working cap/ } \\
\text { Sales }\end{array}$} & \multicolumn{2}{|c|}{$\begin{array}{l}\text { Interest payment/ } \\
\text { VA }\end{array}$} & \multicolumn{2}{|c|}{$\begin{array}{l}\text { VA/ } \\
\text { Assets }\end{array}$} & \multicolumn{2}{|c|}{$\begin{array}{c}\text { Prob. } \\
\text { bankruptcy }\end{array}$} \\
\hline & $\begin{array}{l}\text { Low } \\
{[1]}\end{array}$ & $\begin{array}{l}\text { High } \\
\text { [2] }\end{array}$ & $\begin{array}{l}\text { Low } \\
\text { [3] }\end{array}$ & $\begin{array}{l}\text { High } \\
{[4]}\end{array}$ & $\begin{array}{l}\text { Low } \\
{[5]}\end{array}$ & $\begin{array}{l}\text { High } \\
{[6]}\end{array}$ & $\begin{array}{l}\text { Low } \\
{[7]}\end{array}$ & $\begin{array}{l}\text { High } \\
{[8]}\end{array}$ \\
\hline $\begin{array}{l}\text { Contested } \times \text { Election_year } \\
\quad \times \text { Powerful_MP } \times \text { Involved_bank }\end{array}$ & $\begin{array}{c}.035 \\
(.069)\end{array}$ & $\begin{array}{l}.329 * * * \\
(.118)\end{array}$ & $\begin{array}{l}-.076 \\
(.080)\end{array}$ & $\begin{array}{l}.221 * * * \\
(.082)\end{array}$ & $\begin{array}{l}.194 * * * \\
(.082)\end{array}$ & $\begin{array}{l}-.109 \\
(.090)\end{array}$ & $\begin{array}{l}-.121 \\
(.160)\end{array}$ & $\begin{array}{l}.182 * * * \\
(.068)\end{array}$ \\
\hline Interacted terms & $\checkmark$ & $\checkmark$ & $\checkmark$ & $\checkmark$ & $\checkmark$ & $\checkmark$ & $\checkmark$ & $\checkmark$ \\
\hline Constituencies $\times$ Bank FE & $\checkmark$ & $\checkmark$ & $\checkmark$ & $\checkmark$ & $\checkmark$ & $\checkmark$ & $\checkmark$ & $\checkmark$ \\
\hline Region $\times$ Time FE & $\checkmark$ & $\checkmark$ & $\checkmark$ & $\checkmark$ & $\checkmark$ & $\checkmark$ & $\checkmark$ & $\checkmark$ \\
\hline Bank $\times$ Time FE & $\checkmark$ & $\checkmark$ & $\checkmark$ & $\checkmark$ & $\checkmark$ & $\checkmark$ & $\checkmark$ & $\checkmark$ \\
\hline Constituencies $\times$ Time FE & $\checkmark$ & $\checkmark$ & $\checkmark$ & $\checkmark$ & $\checkmark$ & $\checkmark$ & $\checkmark$ & $\checkmark$ \\
\hline Observations & 48,186 & 48,186 & 48,186 & 48,186 & 48,186 & 48,186 & 48,186 & 48,186 \\
\hline High minus Low & $.293 * *$ & & $.297 * * *$ & & $-.304 * *$ & & $.304 *$ & \\
\hline
\end{tabular}

All regressions are run at the 2-digit-industry, constituency-bank-type-quarter level. Proxies are computed as the average of firms in a given industry. Industries are then split between "low" and "high" types based on the sample median. Dependent variables are the (log of) short-term and total loans to private companies (quarterly frequency). When the incumbent is also a mayor, we account for the municipal election cycle. A constituency is contested if it was held by another party in the previous election or if that actual election result (between the incumbent MP and his closest rival) was decided by less than $6 \%$. An MP is powerful if she is a prominent figure in his party and has direct connections with other elected local politicians. The Involved bank dummy is set to 1 only if the bank has positive local public entity debt on its balance sheet. FE = fixed effects; VA = value-added. Standard errors (in parentheses) are clustered by constituency. $*, * *$, and $* * *$ indicate significance at (respectively) the $10 \%, 5 \%$, and $1 \%$ levels.

Turning now to the economic dynamism of these industries (columns [5]-[8] of the table), we find that most of the additional credit benefited declining sectors; for instance, firms in sectors with low productivity (column [5]) or at greater risk of filing for bankruptcy (column [8]). In both cases, the difference is statistically significant: at no less than the $10 \%$ level for bankruptcy and at the $1 \%$ level for productivity. In terms of economic magnitude, the effect is sizable: declining sectors as well as sectors in need of short-term liquidity benefit from a credit boost of some $20 \%$ during an election year-provided those sectors' firms are within constituencies that feature a contested election involving a powerful politician.

\subsection{Ruling out alternative explanations}

Overall, these results show that the constituencies held by influential politicians benefit from a positive credit supply shock during contested election years. 
That this effect is observed only for banks holding loans to local public entities in their portfolioand not for banks that hold no such loans-is consistent with the reciprocal favors mechanism detailed in Section 6. The most frequently advanced alternative explanation is that the boards of private banks with public entity loans on their balance sheets are also more likely to include politicians who could, in the run-up to an election, directly influence the lending policy of banks that they oversee.

To rule out this account, we start by collecting data on board members of all French cooperative banks, which account for the bulk of the lending to public entities and check to see whether or not they are also politicians (i.e., mayors or MPs). We obtain the board composition from banks' annual prospectuses, which are publicly available for the most recent years on the French regulator's website (AMF). Because any local bank that belongs to a mutual or cooperative bank is legally independent, we can obtain the board information for each separate entity. Hence we collect the information on the three following banking groups: BPCE, Crédit Agricole, and Crédit Mutuel. We find only one MP and and six mayors among the 1,500 board members, which means that the effect we identify cannot be explained simply as politicians directly overseeing banks. Hence we conclude that the "politically controlled bank" explanation does not fit our data.

Another alternative hypothesis that could explain our result is a "specialization" account whereby certain banks concentrate primarily on government-related business and are active in the markets for public entity loans and for loans to firms whose business is due mostly to government contracts. In this case, if powerful incumbents in contested constituencies implement-during election years-demand-side policies that result in more government contracts, then banks lending to local public entities might also be the only ones lending to the private firms who are awarded those government contracts. Hence contractors would demand more credit, and this increased demand would be directed at banks that also hold loans to local public entities on their balance sheet. This would be the case if, for instance, a local hospital plans to expand and the construction contractor is a client of the same bank as the hospital. In such a setting, the econometric interpretation is that we are observing a shock that is correlated with credit volumes 
but also: is specific to election years, occurs in constituencies where an influential incumbent faces a contested election, and affects only those banks that participate in the market for loans to local public entities.

We believe that this hypothesis is unlikely to hold because there is no reason for the firms gaining public contracts to borrow from the same banks as the local public entities themselves. In particular, since the French public procurement procedure follows EU standards and is extremely strict, politicians have limited discretion regarding which firms can be awarded a contractunlike their extensive discretion in choosing the bank that grants loans to local public entities. A salient consequence in our case is that such contractors are seldom in the same constituency as the focal politician.

Nonetheless, we formally rule out this channel by testing for whether the effect just described is driven by firms that gain public procurement contracts. We obtain data-from the public procurement "watchdog" commitee (Observatoire économique de la commande publique)—on which sectors benefit the most from public procurement contracts. These data form the basis of our list of 15 sectors that are responsible for nearly $70 \%$ of the value of public procurement contracts. We then re-run our baseline regression while excluding the private credit extended to firms operating in those sectors and find no quantitative differences in our estimated coefficients. This finding rules out the specialization account.

\section{How do private banks benefit? The reciprocal favors mech- anism}

Why would a bank already active in the market for loans to local public entities increase its supply of credit to the private sector during election years? A possible explanation is that these banks alter credit allocation to curry favor with political clients who could deliver future benefits in return. 
Testing this possibility requires that we identify the most "supportive" banks in an incumbent's reelection effort; however, such support cannot (unfortunately) be observed directly. We circumvent this issue by ranking banks - after removing baseline heterogeneity across constituencies and banks - in terms of how much credit they supply to private firms before an election. To derive this ranking, we regress the volume of credit to private firms granted by each bank on constituency-by-bank fixed effects. The residuals of this regression give us the deviation from the mean lending made by bank $b$ in constituency $c$. In election years, these residuals can be interpreted as looking at the "abnormal supply" of credit provided by bank $b$ in constituency $c$ during such years, or the bank's support (of the incumbent's reelection effort) that we associate with it granting the politician a favor. We then sort banks on this variable in each constituencyelection-year cell as a proxy for which banks made the greatest effort to help that constituency's incumbent in the election. We denote this variable Favor $_{b, c, t}$ and estimate the following regression:

$$
\begin{aligned}
\Delta^{\tau} L_{c, b, t}^{\text {public }}= & \text { Contested }_{c, t}+\text { Powerful_}_{-} \text {PP }_{c, t}+\text { Reelected }_{c, t}+\text { Favor }_{b, c, t} \\
& + \text { Constituency }_{-} \text {characteristics }_{c, t} \otimes \text { Favor }_{b, c, t} \\
& +\beta\left(\text { Reelected }_{c, t}\right) \times \text { Contested }_{c, t} \times \text { Powerful_}_{-} M P_{c, t} \times \text { Favor }_{b, c, t} \\
& +\theta_{c, t}+\delta_{b, t}+\varepsilon_{b, c, t} .
\end{aligned}
$$

In this expression, $\Delta^{\tau} L_{c, b, t}^{\text {public }}$ is the arc percentage change in the volume of lending to local public entities between the election year and $\tau$ years later, $\tau \in\{2,4\}, 28$ Favor $_{b, c, t}$ is the deviation in bank b's supply of credit in constituency $c$ before election $t$ relative to the constituencyelection mean.29 The indicator variable Reelected $_{c, t}$ is set to 1 only if the incumbent from

\footnotetext{
${ }^{28}$ The arc percentage change is computed as $g_{t}=\left(X_{t}-X_{t-1}\right) /\left[\left(X_{t}+X_{t-1}\right) \times 0.5\right]$. This type of growth rate has become standard in the analysis of establishment and firm dynamics because it shares some useful properties with log differences and can also accommodate a large number of zeros (cf. Törnqvist, Vartia, and Vartia (1985); Davis, Haltiwanger, and Schuh (1998)).

${ }^{29}$ More precisely: in the "abnormal supply" regression just described, we compute the mean of the residuals in each
} 
the year- $t$ election is reelected in year $t+1$. We denote by $\otimes$ the outer product, so that the term Constituency characteristics $c, t \otimes$ Favor $_{b, c, t}$ allows for each combination of constituency characteristics (Contested $_{c, t}$, Powerful_ $M P_{c, t}$, and Reelected ${ }_{c, t}$ ) with each other and with the bank variable Favor $_{b, c, t}$. Here the $\theta_{c, t}$ are constituency $\times$ election fixed effects and the $\delta_{b, t}$ are bank $\times$ election fixed effects. Standard errors are clustered at the constituency level.

The inclusion of constituency $\times$ election fixed effects implies that the coefficient of interest $(\beta)$ measures the difference-within the same constituency and for the same election-between the growth of loans to local public entities from banks that helped the politician and the growth from banks that did not help. This comparison reveals whether the most supportive banks in the incumbent's reelection effort gain market share post-election at the expense of other (nonsupportive) banks in the same constituency.

Table 8 presents the regression results. We find that, in constituencies with a contested powerful incumbent, a pre-election increase in credit supply to the private sector leads to an increase in the amount of loans to local public entities in the two years (columns [1] and [2]) and four years (columns [3] and [4]) after the election. Consistently with the interpretation of a powerful MP returning the favor, this positive effect is observed only if the incumbent is reelected; if the incumbent loses, then the most supportive banks see a reduction in their market shares. Results are strongly similar when we include bank $\times$ election fixed effects to account for time-varying shocks at the bank level, which could be driving not only the private sector's supply of credit but also the propensity of banks to lend to local public entities.

The total debt of local public entities that we observe on banks' balance sheets is actually the sum of two distinct components that can be identified in the data: (i) local debt controlled by local politicians; ${ }^{30}$ and (ii) local debt controlled by the central government. ${ }^{31}$ In Table 9 we constituency-election cell and then rank the banks according to the size of their abnormal supply relative to this mean by taking the mean deviation (in percentage). This is our variable Favor ${ }_{b, c, t}$.

${ }^{30}$ Local politicians have control over how to allocate the debt because it is either issued directly by the local government (municipalities or regional council) or issued by local public entities controlled by local politicians, e.g. hospitals .

${ }^{31}$ There is central government control of local debt that is issued by local services (e.g., public housing) of the 
Table 8 - Evidence for Reciprocal Favors-Banks' Rewards

\begin{tabular}{|c|c|c|c|c|}
\hline \multirow[t]{2}{*}{ Dependent variable } & \multicolumn{2}{|c|}{$\Delta^{2} L_{c, b, n}^{\text {public }}$} & \multicolumn{2}{|c|}{$\Delta^{4} L_{c, b, n}^{\text {public }}$} \\
\hline & [1] & [2] & [3] & [4] \\
\hline $\begin{array}{l}\text { Contested } \times \text { Powerful__MP } \times \text { Favor } \\
\quad \times \text { Reelected }\end{array}$ & $\begin{array}{l}.749 * * * \\
(.295)\end{array}$ & $\begin{array}{l}.623 * * \\
(.274)\end{array}$ & $\begin{array}{l}.870 * * * \\
(.354)\end{array}$ & $\begin{array}{l}.806^{* * *} \\
(.333)\end{array}$ \\
\hline Contested $\times$ Powerful_ MP $\times$ Favor & $\begin{array}{l}-.661^{* * *} \\
(.248)\end{array}$ & $\begin{array}{c}-.535^{* *} \\
(.230)\end{array}$ & $\begin{array}{c}-.699 * * * \\
(.289)\end{array}$ & $\begin{array}{l}-.617^{* *} \\
(.273)\end{array}$ \\
\hline Interacted terms & $\checkmark$ & $\checkmark$ & $\checkmark$ & $\checkmark$ \\
\hline Constituencies $\times$ Election FE & $\checkmark$ & $\checkmark$ & $\checkmark$ & $\checkmark$ \\
\hline Bank $\times$ Election FE & - & $\checkmark$ & - & $\checkmark$ \\
\hline Observations & 94,220 & 94,220 & 87,811 & 87,811 \\
\hline
\end{tabular}

The dependent variable is the arc percentage change in volume of lending to local public entities between election year $t$ and $t+2$ (columns [1] and [2]) or $t+4$ (columns [3] and [4]). That change is computed as $g_{t}=\left(X_{t}-X_{t-1}\right) /\left[\left(X_{t}+\right.\right.$ $\left.\left.X_{t-1}\right) \times 0.5\right]$. The Favor variable is the percentage difference between the private credit granted by a given bank within its constituency and the constituency mean in election year $t$; Reelected is a dummy set equal to 1 if the incumbent running in year $t$ is reelected (and is otherwise set to 0 ). FE = fixed effects. Standard errors (in parentheses) are clustered by constituency. $*, * *$, and $* * *$ indicate significance at (respectively) the $10 \%, 5 \%$, and $1 \%$ levels.

reproduce our analysis separately for debt controlled by local politicians (columns [1] and [3]) and debt controlled by the central government (columns [2] and [4]). Consistently with our reciprocal favors hypothesis, we find that the increase in public debt following an incumbent's reelection is is observed only for the public debt that local politicians can influence. Thus banks that lent more to the private sector during election years did not, at the same time, experience a change in their share of local public debt controlled by the central government.

Finally, we investigate the "historical dependency" of the reciprocal favors mechanism by referring to Tables 8 and 9. When the incumbent is not reelected, we find that an increase in the supply of credit to the private sector during an election year actually leads to a reduction in the amount of loans to local public entities on banks' balance sheets: the coefficient for Contested $\times$ Powerful_MP $\times$ Favor is negative and significant at the $5 \%$ level. This is a key finding because it enables our ruling out a bank-constituency-specific shock that simultaneously affects the volumes of credit extended to local private firms and to local public entities. Indeed, central government. 
Table 9 - Evidence for Reciprocal Favors-Banks' Rewards Decomposed

\begin{tabular}{|c|c|c|c|c|}
\hline \multirow{2}{*}{$\begin{array}{l}\text { Dependent variable } \\
\text { Politicians controlling public debt }\end{array}$} & \multicolumn{2}{|c|}{$\Delta^{2} L_{c, b, n}^{\text {public }}$} & \multicolumn{2}{|c|}{$\Delta^{4} L_{c, b, n}^{\text {public }}$} \\
\hline & $\begin{array}{l}\text { Local } \\
{[1]}\end{array}$ & $\begin{array}{l}\text { Central } \\
\text { [2] }\end{array}$ & $\begin{array}{c}\text { Local } \\
{[3]}\end{array}$ & $\begin{array}{c}\text { Central } \\
{[4]}\end{array}$ \\
\hline $\begin{array}{l}\text { Contested } \times \text { Powerful__MP } \times \text { Favor } \\
\quad \times \text { Reelected }\end{array}$ & $\begin{array}{l}.624^{* *} \\
(.279)\end{array}$ & $\begin{array}{l}.109 \\
(.097)\end{array}$ & $\begin{array}{l}.685^{* *} \\
(.326)\end{array}$ & $\begin{array}{c}.022 \\
(.102)\end{array}$ \\
\hline Contested $\times$ Powerful_ $M P \times$ Favor & $\begin{aligned}-.469 * * * \\
\\
(.198)\end{aligned}$ & $\begin{array}{l}-.110 \\
(.073)\end{array}$ & $\begin{array}{c}-.333^{* *} \\
(.125)\end{array}$ & $\begin{array}{l}-.045 \\
(.0701)\end{array}$ \\
\hline Interacted terms & $\checkmark$ & $\checkmark$ & $\checkmark$ & $\checkmark$ \\
\hline Constituencies $\times$ Election FE & $\checkmark$ & $\checkmark$ & $\checkmark$ & $\checkmark$ \\
\hline Bank $\times$ Election FE & $\checkmark$ & $\checkmark$ & $\checkmark$ & $\checkmark$ \\
\hline Observations & 94,220 & 94,220 & 87,811 & 87,811 \\
\hline
\end{tabular}

The dependent variable is the arc percentage change in volume of lending to local public entities between election year $t$ and $t+2$ (columns [1] and [2]) or $t+4$ (columns [3] and [4]); it is computed as $g_{t}=\left(X_{t}-X_{t-1}\right) /\left[\left(X_{t}+X_{t-1}\right) \times 0.5\right]$. Total debt of local public entities is decomposed into debt controlled (a) by local politicians (local government and entities controlled by local politicians) in columns [1] and [3] and (b) by the central government in columns [2] and [4]. As before, Favor is the percentage difference between the private credit granted by a given bank within its constituency and the constituency mean during election year $t$, and Reelected is an indicator set to 1 only if the incumbent running in year $t$ is reelected. FE = fixed effects. Standard errors (in parentheses) are clustered by constituency. *, **, and *** indicate significance at (respectively) the $10 \%, 5 \%$, and $1 \%$ levels.

if that were the case then we should also observe a positive link-between the bank supply of credit to private firms and the growth of loans to local public entities_during the years following an election in which the incumbent is not reelected. However, our results are more consistent with the newly elected politician "punishing" banks that favored the former incumbent.

\section{Conclusion}

This paper provides evidence that - even with low levels of corruption, a limited need for (or possibility of) government bailouts, and full formal separation between politicians and bankgoverning institutions - private banks may be motivated, by the possibility of future benefits, to distort their supply of credit to the local economy so as to curry favor with powerful politicians during election years. 
Such incentives arise because private banks can thereby gain access to a profitable segment of the debt market: loans to local public entities. In France, influential politicians can reciprocate the favor of higher credit to the local economy during a contested election by ensuring the bank's access to the public entity loan market-because that market is not regulated and so nearly all allocation of loans to banks is discretionary.

This quid pro quo is possible because loan contracts to local public entities are not subject to the Public Procurement Code, a loophole that is not unique to France. In several countries, loan contracts are governed by private law and are therefore exempt from tendering and procurement legislation. Hence some aspects of stricter regulation (e.g., requiring that firms call for tenders) may not be enforceable. In the absence of an applicable code, politicians' ethical behavior could still be encouraged by the central government's promoting transparency and accountability with respect to the credit contracted by local governments. For example, the public reporting of credit contract characteristics-especially the interest rate and maturity - would reduce the asymmetry of information between an incumbent and her electorate and thus, one would hope, reduce the spread on credit to public loans. One benefit of such a policy would be the subsequent positive fiscal impact. Overall, our findings highlight the need for research to transcend easily observed channels so that we may gain a broader appreciation of the full role of bank influence in politics, better understand the possible distortions due to influence-seeking behaviors, and more completely picture the optimal form of regulation. 


\section{References}

Adelino, M., and I. S. Dinc. 2014. "Corporate distress and lobbying: Evidence from the Stimulus Act." Journal of Financial Economics 114 (2): 256-272.

Akey, P. 2015. "Valuing Changes in Political Networks: Evidence from Campaign Contributions to Close Congressional Elections." Review of Financial Studies 28 (11): 3188-3223.

Akey, P., C. Dobridge, R. Z. Heimer, and S. Lewellen. 2018. "Pushing Boundaries : Political Redistricting and Consumer Credit." Working Paper 1 (647).

Akey, P., R. Z. Heimer, and S. Lewellen. 2018. "Politicizing Consumer Credit." Working Paper.

Amore, M. D., and M. Bennedsen. 2013. "The value of local political connections in a lowcorruption environment." Journal of Financial Economics 110 (2): 387-402.

Ansolabehere, S., J. M. de Figueiredo, and J. M. Snyder. 2003. "Why Is There so Little Money in U.S. Politics?" Journal of Economic Perspectives 17 (1): 105-130.

Antoniades, A., and C. W. Calomiris. 2018. Mortgage Market Credit Conditions and U.S. Presidential Elections. Working Paper, Working Paper Series 24459. National Bureau of Economic Research, March.

Bach, L. 2011. "Politicians with Many Principals: Theory and Evidence from France." Working Paper.

Baker, S. R., N. Bloom, and S. J. Davis. 2016. "Measuring Economic Policy Uncertainty." Quarterly Journal of Economics 131 (4): 1593-1636.

Bertrand, M., M. Bombardini, and F. Trebbi. 2014. "Is It Whom You Know or What You Know? An Empirical Assessment of the Lobbying Process." American Economic Review 104 (12): 3885-3920. 
Bertrand, M., F. Kramarz, A. Schoar, and D. Thesmar. 2018. "The cost of political connections." Review of Finance 22 (3): 849-876.

Bian, B., R. Haselmann, T. Kick, and V. Vig. 2018. "The Political Economy of Bank Bailouts." Working Paper.

Bian, B., R. Haselmann, and V. Vig. 2017. "Government Ownership of Banks and Corporate." Working Paper, no. January.

Bircan, C., and O. Saka. 2019. "Lending Cycles and Real Outcomes: Costs of Political Misalignment." Working Paper, no. 139.

Brown, C. O., and I. S. Dinç. 2005. "The Politics of Bank Failures: Evidence from Emerging Markets." Quarterly Journal of Economics 120 (4): 1413-1444.

Carvalho, D. 2014. “The Real Effects of Government-Owned Banks: Evidence from an Emerging Market." The Journal of Finance 69 (2): 577-609.

Chavaz, M., and A. K. Rose. 2018. Political Borders and Bank Lending in Post-Crisis America. Technical report. August.

Claessens, S., E. Feijen, and L. Laeven. 2008. "Political connections and preferential access to finance: The role of campaign contributions." Journal of Financial Economics 88 (3): $554-580$.

Cohen, L., and C. J. Malloy. 2014. "Friends in High Places." American Economic Journal: Economic Policy 6 (3): 63-91.

Cole, S. 2009. "Fixing market failures or fixing elections? Agricultural credit in India." American Economic Journal: Applied Economics 1 (1): 219-50.

Davis, S. J., J. C. Haltiwanger, and S. Schuh. 1998. Job creation and destruction [in English]. 1st MIT Pr. Cambridge, Mass: MIT Press. 
Dinç, I. S. 2005. "Politicians and banks: Political influences on government-owned banks in emerging markets." Journal of financial economics 77 (2): 453-479.

Duchin, R., and D. Sosyura. 2012. "The politics of government investment." Journal of Financial Economics 106 (1): 24-48.

Englmaier, F., and T. Stowasser. 2017. "Electoral cycles in savings bank lending." Journal of the European Economic Association 15 (2): 296-354.

Faccio, M. 2006. "Politically Connected Firms." American Economic Review 96 (1): 369-386.

Faccio, M., and H.-C. Hsu. 2017. "Politically Connected Private Equity and Employment." The Journal of Finance 72 (2): 539-574.

Faccio, M., R. W. Masulis, and J. J. McConnell. 2007. "Political Connections and Corporate Bailouts." Journal of Finance 61 (6): 2597-2635.

Faccio, M., and D. C. Parsley. 2009. "Sudden Deaths: Taking Stock of Geographic Ties." Journal of Financial and Quantitative Analysis 44 (3): 683-718.

Ferguson, T., and H.-J. Voth. 2008. "Betting on Hitler: The Value of Political Connections in Nazi Germany." Quarterly Journal of Economics 123 (1): 101-137.

Fishback, P. V., M. R. Haines, and S. Kantor. 2007. "Births, Deaths, and New Deal Relief during the Great Depression." The Review of Economics and Statistics 89 (1): pp. 1-14.

Fraisse, H., J. Hombert, and M. Lé. 2018. "The competitive effect of a bank megamerger on credit supply." Journal of Banking and Finance 93:151-161.

Goldman, E., J. Rocholl, and J. So. 2013. "Politically Connected Boards of Directors and The Allocation of Procurement Contracts." Review of Finance 17 (5): 1617-1648.

Grossman, G. M., and E. Helpman. 2001. Special interest politics [in English]. Cambridge, Mass: MIT. 
Gulen, H., and M. Ion. 2015. "Policy Uncertainty and Corporate Investment." Review of Financial Studies 29 (3): 523-564.

Haselmann, R., D. Schoenherr, and V. Vig. 2018. "Rent Seeking in Elite Networks." Journal of Political Economy 126 (4): 1638-1690.

Jens, C. E. 2017. "Political uncertainty and investment: Causal evidence from U.S. gubernatorial elections." Journal of Financial Economics 124 (3): 563-579.

Julio, B., and Y. Yook. 2012. "Political Uncertainty and Corporate Investment Cycles." Journal of Finance 67 (1): 45-83.

Kang, K. 2016. "Policy Influence and Private Returns from Lobbying in the Energy Sector." Review of Economic Studies 83 (1): 269-305.

Kara, G., and Y. Yook. 2019. "Policy Uncertainty and Bank Mortgage Credit." Working Paper.

Khwaja, A. I., and A. Mian. 2005. "Do lenders favor politically connected firms? Rent provision in an emerging financial market." The Quarterly Journal of Economics 120 (4): 1371-1411.

Koetter, M., and A. Popov. 2019. "Political Cycles in Banks' Government Lending." Working Paper.

Mian, A., A. Sufi, and F. Trebbi. 2010. "The Political Economy of the US Mortgage Default Crisis." American Economic Review 100 (5): 1967-1998.

Nguyen, B. D., and K. M. Nielsen. 2010. "The value of independent directors: Evidence from sudden deaths." Journal of Financial Economics 98 (3): 550-567.

Nordhaus, W. D. 1975. "The political business cycle." The Review of Economic Studies 42 (2): 169-190.

Olken, B. A., and R. Pande. 2012. "Corruption in Developing Countries." Annual Review of Economics 4:479-509. 
Pérignon, C., and B. Vallée. 2017. "The Political Economy of Financial Innovation: Evidence from Local Governments." Review of Financial Studies 30 (6): 1903-1934.

Sapienza, P. 2004. "The effects of government ownership on bank lending." Journal of financial economics 72 (2): 357-384.

Schoenherr, D. 2019. "Political Connections and Allocative Distortions." Journal of Finance 74 (2): 543-586.

Tahoun, A. 2014. "The role of stock ownership by US members of Congress on the market for political favors." Journal of Financial Economics 111 (1): 86-110.

Törnqvist, L., P. Vartia, and Y. O. Vartia. 1985. "How Should Relative Changes be Measured?" American Statistician 39 (1): 43-46.

Vidal, J. B. i, M. Draca, and C. Fons-Rosen. 2012. "Revolving Door Lobbyists." The American Economic Review 102 (7): 3731-3748.

Weatherford, M. S. 1978. "Economic Conditions and Electoral Outcomes: Class Differences in the Political Response to Recession." American Journal of Political Science 22 (4): 917938. 


\section{Appendix: Construction of political variables}

\section{A.1 Incentives of the incumbent}

We use the extent of political competition to proxy for valuation of election favors by the incumbent MP. That extent is determined by the following inputs.

1. Upcoming contested elections. We define "close" elections as those decided by a small margin. More precisely, we use actual election results to compute the difference between: (a) the votes received by the incumbent MP and those received by his closest rival in the round during which that incumbent wins the election; or (b) the votes received by the newly elected MP and those by the incumbent MP in the round during which the incumbent loses. We then create the dummy variable Contested_election, which is set to 1 only if this winning margin is less than $6 \%$ (though our results are robust to winning margins that range from $2 \%$ to $14 \%) 32$

2. Not a party stronghold. For an incumbent, we say that a constituency is not a stronghold of her party if, before the preceding election, that constituency was held by another party.

\section{A.2 Political power of the incumbent}

We assess an incumbent's power in terms of his influence within the party and his likelihood of being supported by other politicians in the same party.

Our proxies for influence within the incumbents' party are based on two factors.

1. The incumbent has significant political longevity. We create the Powerful_MP indicator, which is set to 1 only if the incumbent held an MP office at least three times before the

\footnotetext{
${ }^{32}$ Given the small error margins, we use actual election results instead of poll data.
} 
focal election. We consider political longevity across constituencies by counting the total number of an MP's mandates (even if they were completed in different constituencies). We also account for alternate MP elections and for by-elections.

2. The incumbent has had a political career at the national level. Following Bertrand, Kramarz, Schoar, and Thesmar (2018), we identify the set of incumbents that previously served as a minister (or secretary of state) in one of the 22 governments of the Fifth Republic. ${ }^{33}$

Finally, we use the following inputs to devise our proxy for the incumbent's ability to influence other politicians.

1. The incumbent is supported by the central government. We identify the set of incumbents who are members of the political party in office in the central government.

2. The incumbent is supported by the regional government. We identify the set of incumbents who are members of the political party in office in the regional council, which is in charge of regional economic development 34

3. The incumbent is supported by the mayors in her constituency. We identify the set of incumbents who are supported -in terms of party affiliation-by more than $50 \%$ of the mayors in her constituency. (Similar results are obtained when we use cutoff values of $40 \%$ and $60 \%$.)

\footnotetext{
${ }^{33}$ The list of ministers and secretaries of state is from the French Home Affairs. The Fifth Republic was introduced by a change in the Constitution Law effective 4 October 1958, and that regime has extended to this day.

${ }^{34}$ We collect data for the Regional Council election from 2008 to 2016. Here our indicator is set to 1 only if the incumbent is from the same party as the regional council at least one year before a parliamentary election; note that the elections for parliament and regional council are not synchronized.
} 